\title{
Application of Geospatial Techniques and Logistic Regression Model for Urban Growth Analysis in Limbe, Cameroon
}

\author{
Adzandeh E. A. ${ }^{1}$, Alaigba, D. ${ }^{2}$ and Nkemasong C. N. ${ }^{3} *$ \\ ${ }^{1,2,3}$ African Regional Institute for Geospatial Information Science and Technology (AFRIGIST), Obafemi \\ Awolowo University, Ile-Ife, Osun State, Nigeria \\ Corresponding Author: *nkemcelesto@gmail.com
}

https://doi.org/10.36263/nijest.2020.01.0193

\begin{abstract}
Little is known about the nature of ecosystem loss, rampant changes in land use and land cover (LULC) and urban growth taking place in Limbe. The aim of this study is to analyze urban growth in Limbe, Cameroon from 1986-2019 using geospatial techniques and Logistic Regression Model (LRM). Landsat Thematic Mapper (1986), Enhanced Thematic Mapper+ (2002) and Operational Land Imagery/Thermal Infrared Sensor (2019) were utilized in this study. The images were classified into land cover classes using supervised image classification algorithm in ENVI software. The classification output was subjected to LRM application to evaluate urban growth. Image difference of urban growth between 1986 and 2019 was calculated as dependent variable and the independent variables were produced by calculating the Euclidean distance and Buffer of built-up, waterbody, road and farmland as driving factor for urban growth. Future urban growth was determined for 2035 using the Land Change Modeler in IDRISI Selva. Classification overall accuracy for the three date were not less than 99\%. LRM results show a good fit with relative operation characteristic of 0.8344 and Pseudo $R^{2}$ of 0.21 . Analysis of LULC shows that built-up increased from $3.5 \%$ (1986) to $17.6 \%$ (2019). An urban land expansion rate of about $23 \%$ was observed for 2035. Transition probability matrix revealed high probability (0.6345) of build-up to remaining build-up by 2035, while the probability for it changing to waterbody, bare land, farm land and vegetation are 0.1099, 0.0459, 0.1939 and 0.1221, respectively. This study successfully demonstrates the application of geo-spatial techniques and LRM for land use/land cover change detection and in understanding the urban growth dynamics. It also identifies the potential areas of future urban growth, which can help land use policy planners for making optimum decisions of land use planning and investment.
\end{abstract}

Keywords: Limbe, Logistic Regression Model, Spatial Analysis, Urban Growth

\subsection{Introduction}

City landscapes have been rapidly changing in the last few decades in response to accelerated population growth and the transition from rural to urban areas (Omar et al., 2017). Urban growth has been accelerating with the significant increase in urban population. Human transformation of the ecosystems and landscapes are the largest source of change in the natural systems on Earth, affecting the ability of the biosphere to sustain life (Yu Nong, 2011). Anjolajesu (2016) submitted that man depends on the environment for survival, and the environment also depends on man for sustenance.

Rapidly growing urbanization of our cities and villages overpowers the meager resources by encroaching them which leads to unmanaged and unsustainable development situation. We can manage Urban Growth in a planned way by planning future scenarios for which land use land cover area change dynamics is crucial to understand (Ankita, 2016). To achieve a sustainable development, cities must be planned and managed to form a balance between human beings and natural environment by using resources carefully and transferring them to the next generation. According to (UN-Habitat, 2017), localization of Sustainable Development Goals (SDGs) in cities demands up-todate spatial information to accommodate changes in planning, monitoring, and evaluation of urban planning. 
Sustainable development must meet "the needs of the present without compromising the ability of future generations to meet their own needs (UN-WCED, 1987). According to (UN, 2016), cities in developing countries are struggling to provide up-to-date spatial information reflecting urban dynamics in order to protect and enhance environmental conditions. Geographic Information Systems (GIS) and remote sensing techniques provide effective tools in studying and monitoring landuse/land-cover change over space and time (Addae, 2019).

Urban growth when occurs in an unplanned and unmanaged way it will hamper the quality of growth in a region. Impacts on wildlife and ecosystem in areas where sprawl is not controlled would lead to disturbances in ecosystem and processes (Grimm et al., 2000). Urban sprawl decreases the amount of agriculture, forests and water bodies (Hedblom, 2010). Urban sprawl is also blamed for the poor health of society due to increased pollution (Brueckner, 2011). LRM was chosen because The Relative Operation Characteristic (ROC) is an excellent method to compare a map of "reality" versus a suitability map according to (Hossein, 2019). ROC of 1 indicates no growth while 1 indicates the presence of urban growth.

This study is to detect and analyze the spatio-temporal changes in the urban LUC of Limbe between 1986-2019, examines the driving factors that influence urban growth and predict LUC in 2035 using Logistic Regression Model (Arafan, 2017). This is in line with the Cameroon Vision 2035 that outlines the goals and priorities for the country in becoming an emerging economy by 2035 . This study is different from others in that it uses the 4 variable model which has a greater impact on urban growth. This study shows that urban growth is gearing towards built up areas, farm lands, waterbodies and roads. This will go a long way to help land use policy planners for making optimum decisions of land use planning and investment.

\subsection{Methodology}

\subsection{Description of the study area}

Limbe is a seaside city located along the coastal area of Fako Division, South-Western region of Cameroon. The study area lies within Latitudes $4^{\circ} 4^{\prime} 4.3^{\prime \prime} \mathrm{N}$ and $3^{\circ} 56^{\prime} 53.8^{\prime \prime} \mathrm{N}$; Longitudes $9^{\circ} 11^{\prime} 43.9^{\prime \prime} \mathrm{E}$ and $9^{\circ} 12^{\prime} 45.6^{\prime \prime} \mathrm{E}$ (see Figure 1). It has a surface area of $185 \mathrm{~km}^{2}$ and a population of 120,000 inhabitants in 2014 statistics, with tropical equatorial climate of hot, moist, and dry conditions (Ndille et al., 2014 and Folack, 2003). The topography is characterized by low-lying coastal plain, rising to a chain of horseshoe shaped hills with slopes of varying intensities with the highest points reaching $362 \mathrm{~m}$ above sea level (Njabe, 2006). It is only about 10 miles from Dibuncha and is the second wettest place in the world after Cherrapunji in India (UNU-EHS, 2010). Limbe experiences very heavy torrential rains in the long rainy season (March-October) with the highest average monthly precipitation of about $700 \mathrm{~mm}$ recorded in June, July, and August (Roland, 2014).

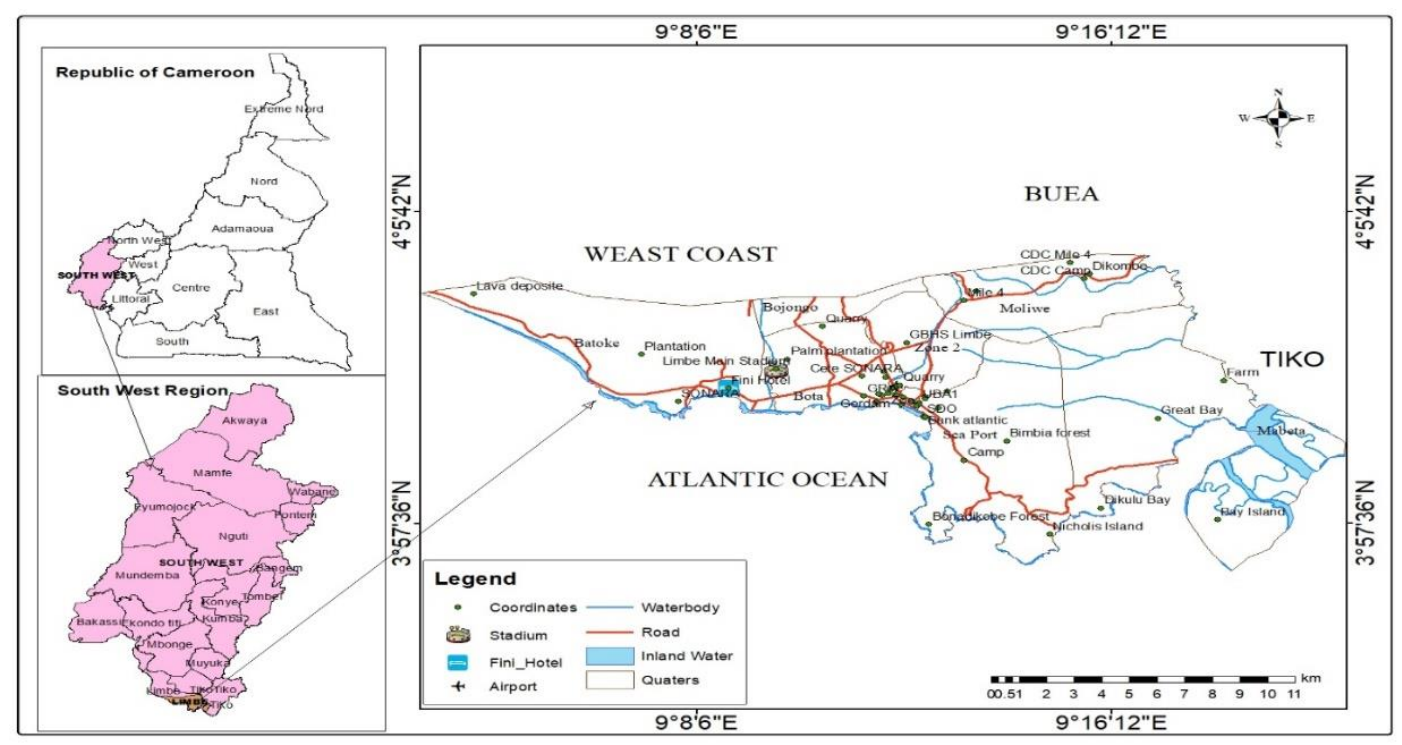

Figure 1: Study area 


\subsection{Data collection}

Two types of data were used in this research. Satellite data that comprised of three years' multitemporal satellite imageries (LANDSAT_5 for 1986, LANDSAT_7 for 2002 and LANDSAT_8 for 2019) and Global Positioning System (GPS) coordinates acquired from field survey. The Landsat images were acquired during the day in the months of January and December from the United States Geological Surveys (USGS) official website. Detailed information regarding the Landsat characteristics is provided in Table 1.

Table 1: Characteristics of Landsat dataset for the study period

\begin{tabular}{lllll}
\hline Data & Path and Row & Type & Resolution & Image date \\
\hline Landsat 5 TM & 187057 & Raw data & $30 \mathrm{~m}$ & $1986 / 12 / 12$ \\
Landsat 7 ETM+ & 187057 & Raw data & $30 \mathrm{~m}$ & $2002 / 01 / 30$ \\
Landsat 8 OLI/TIRS & 187057 & Raw data & $30 \mathrm{~m}$ & $2019 / 01 / 05$ \\
\hline
\end{tabular}

Field survey data is very important for ground trothing. It is used to assess the accuracy of the classified land cover map. A total of 40 selected ground truth points were collected and used to ground check the zones using a held GPS Garmin of $2 \mathrm{~m}$ accuracy.

\subsection{Land use/land cover characterization between 1986-2019}

Three Landsat images of 1986, 2002 and 2019 were used to analyze the spatial pattern of expansion of Limbe City for a period of 33 years. The LULC classification rules for satellite imagery were followed according to the manual of Nation-wide LULC mapping, National Remote Sensing Agency (NRSC, 2014). The datasets were preprocessed in ENVI 5.1 software environment for colour composite, image sub-setting on the basis of Region of Interest (ROI) followed by band combination and layer stacking. Supervised Maximum Likelihood classification was used because it is popular and the most common method in remote sensing image data analysis (Rawat, 2015). This was done to draw out useful thematic information (Boakye, 2008).

Table 2: Land cover class and definitions for supervised classification

\begin{tabular}{|c|c|c|}
\hline $\mathrm{S} / \mathrm{N}$ & Land cover classes & Description \\
\hline 1 & Farmland & $\begin{array}{l}\text { The land which is mainly used for growing food crops such as maize, green grams, } \\
\text { beans, cassava, mangos }\end{array}$ \\
\hline 2 & Build up Area & $\begin{array}{l}\text { This class describes the land covered with buildings in the rural and urban. It includes } \\
\text { commercial, residential, industrial and transportation infrastructures }\end{array}$ \\
\hline 3 & Bare Land & $\begin{array}{l}\text { This describes the land left without vegetation cover. This result from abandoned crop } \\
\text { land, eroded land due to land degradation and weathered road surface. }\end{array}$ \\
\hline 4 & Vegetation & $\begin{array}{l}\text { Deciduous forest land, evergreen forest land, mixed forest land, orchards, groves, } \\
\text { vineyards, nurseries, ornamental horticultural area }\end{array}$ \\
\hline 5 & Waterbody & $\begin{array}{l}\text { This class of land cover describes the areas covered with water either along the river } \\
\text { bed or man-made earth dams, filled sand dams and ponds. }\end{array}$ \\
\hline
\end{tabular}

\subsection{Analysis of urban growth using logistic regression model}

Urbanization rate involves the analysis of the rate of expansion by using the build-up land cover class. Here we calculate the area gain and loss by build-up class from and to other land use /land cover classes for the study periods of 1986-2002, and 2002-2019 (Eastman, 2015). The land cover maps produced from previous process were reclassified into two main land cover types: urban area and nonurban area. The urban growth analysis conducted resulted in urban growth image which happened between 1986-2019, its transition matrix and the probability of change. Only the transition matrix and change probability of urban growth were used as dependent variable to build the logistic regression of urban growth.

\subsubsection{Logistic Regression}

A logistic regression model was used to model urban growth and generate an urban growth map. This regression model is useful for predicting the presence or absence of a characteristic or outcome based on values of a set of predictor variables. The dependent variable represents urban growth results, Y has a binary value of 1 and 0 for Yes and No, respectively. Actually, the probability reflects in what extend $\mathrm{Y}$ will change into 1, as shown in Equation 1 (Nong, 2011). P could be very close to 0 or 1. 
$P\left(Y=1 \mid X_{1}, X_{2}, \ldots X_{n}\right)=\frac{1}{1+e^{\alpha \sum_{1}^{n} \beta_{1} x_{1}}}$

Where:

$P\left(Y=1 \mid X_{1}, X_{2} \ldots X_{n}\right)$ is the probability of $\mathrm{Y}$ given by $X_{i}(i=1,2 \ldots n)$ and changes from non-urban to urban land. Moreover, $1-\mathrm{P}$ is the probability of presence of no urban growth. The logistic transformation is shown in Equation 2:

$\ln \left(\frac{p}{1-p}\right)=\alpha+\beta_{1} X_{1}+\cdots+\beta_{n} X_{n}$

The urban growth in this research was done using the statistical logistic regression method which uses the net urban growth of the year 1986 and 2019 as dependent variable and the driving factors as independent variables. The dependent variable was produced by calculating the image difference of urban growth between 1986 and 2019. While the independent variables were produced by calculating the buffer and Euclidean to built-up, waterbody, road and agriculture land which were the socioeconomic driving factor for urban growth (Ashfa, 2015). The result was then used as input for building the logistic regression model.

\subsection{Future growth prediction for the year 2035}

The Markov Chain Analysis was used to model land use change. It is a process in which the future state of a system can be modeled on the basis of the immediately preceding state by developing a transition probability matrix from period one to period two which shows the nature of change but no knowledge of spatial distribution. The above prediction date was chosen in line with the Cameroon Vision 2035 that outlines the goals and priorities for the country in becoming an emerging economy by 2035 .

Markov modules from TerrSet were used to calculate the probability of a Markov transition and to generate a transition probability matrix. Markov transition probabilities were calculated from cross tabulations using beginning LUC (2002) and end LUC (2019). Figure 2 shows a breakdown of the methodology adopted for the study.

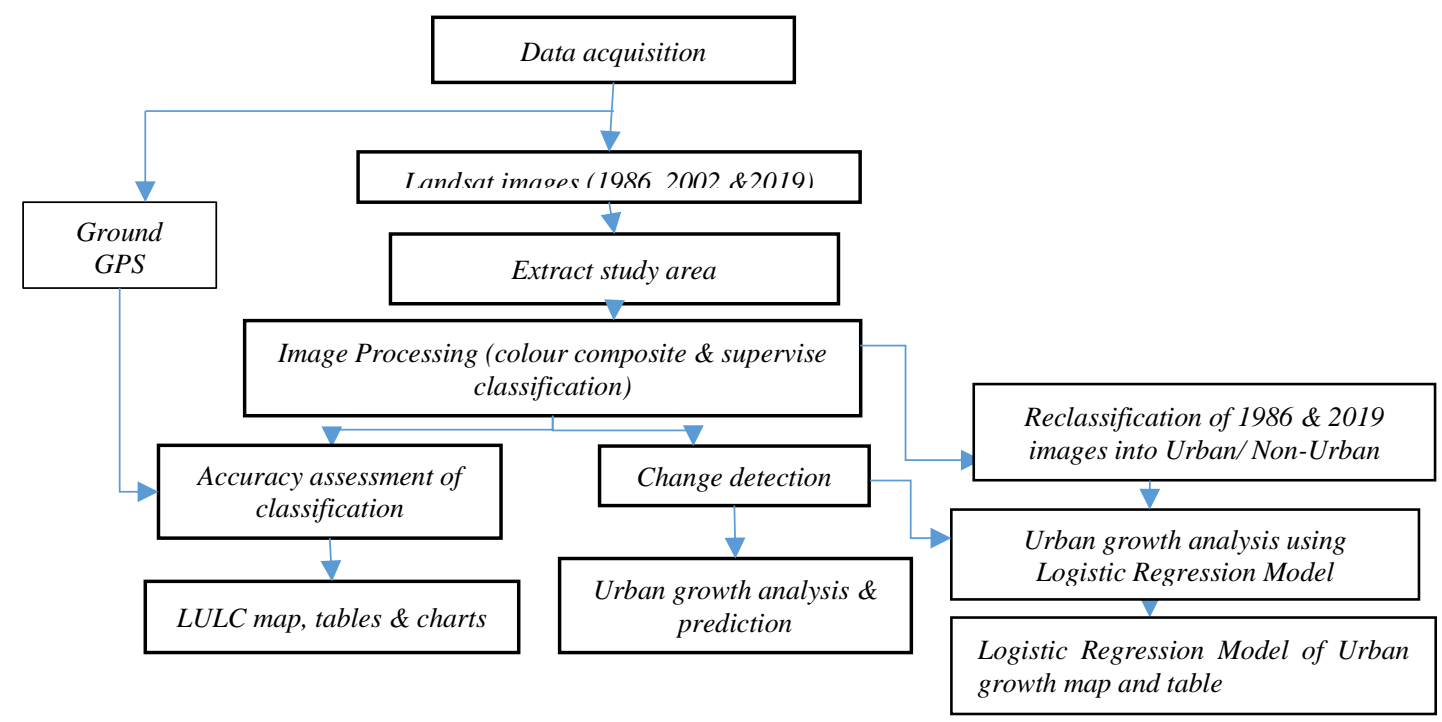

Figure 2: Flow chart methodology

\subsection{Results and Discussion}

\subsection{Analysis of land use/land cover}

Landsat images of 1986, 2002 and 2019 were classified using ground truth information and visual interpretation into built up, waterbody, farm land, bare land and vegetation. The results of image classification conducted in 1986, 2002 and 2019 for this study is presented in Table 3. Accuracy 
assessment was performed for the three dates and result not less than 99\% (Zheng et al., 2015). Figures 3 to 5 depicts the LULC maps for the three dates (1986, 2002 and 2019).

Table 3: Analysis of LULC distribution (1986-2019)

\begin{tabular}{|c|c|c|c|c|c|c|}
\hline & 1986 & & 2002 & & 2019 & \\
\hline LULC & Area $\left(\mathrm{km}^{2}\right)$ & $(\%)$ & Area $\left(\mathrm{km}^{2}\right)$ & $(\%)$ & Area $\left(\mathrm{km}^{2}\right)$ & $(\%)$ \\
\hline Built up & 7.88 & 3.58 & 26.45 & 12.01 & 38.76 & 17.60 \\
\hline Waterbody & 3.22 & 1.46 & 4.16 & 1.89 & 3.39 & 1.54 \\
\hline Bare land & 22.14 & 10.06 & 53.90 & 24.48 & 0.91 & 0.41 \\
\hline Farm land & 11.85 & 5.38 & 17.17 & 7.80 & 31.01 & 14.08 \\
\hline Vegetation & 175.13 & 79.53 & 118.54 & 53.83 & 146.14 & 66.37 \\
\hline Total & 220.22 & 100 & 220.22 & 100 & 220.22 & 100 \\
\hline & \multicolumn{2}{|c|}{$\begin{array}{l}\text { Overall accuracy = } \\
99.3180 \% \\
\text { Kappa }=0.9882\end{array}$} & \multicolumn{2}{|c|}{$\begin{array}{l}\text { Overall accuracy = } \\
99.8245 \%\end{array}$} & \multicolumn{2}{|c|}{$\begin{array}{l}\text { Overall accuracy = } \\
99.8844\end{array}$} \\
\hline
\end{tabular}

The classification results indicate that Built-up area in 1986 occupies $3.58 \%$ of the total land. Vegetation has the highest area class with $79.53 \%$, due to the fact that the town is located at the coast mostly inhabited by the white men. Bare land has the second highest with $10.06 \%$ while farm land was $5.38 \%$. In 2002 , built up area occupies $12.01 \%$ as a result of increase in population and development associated with urbanization where rooms were made for the Cameroon Development Cooperation to surrender part of the Palm plantation for the creation of layouts. Farming activities seems to have increased by $2.42 \%$, this can be attributed to rural exodus. The bare land covers $24.48 \%$ compared to $10.06 \%$ in 1986 which was as a result of the June 2001landslides that took placed in Limbe destroying over 120 houses and transforming vegetation and some built up into bare land. Vegetation cover reduced to $53.83 \%$ as compared to $79.53 \%$ possibly as a result of the abovementioned landslides (Ayonghe et al, 2004), bush fire and deforestation. Also, the water percentage rose to $1.89 \%$ compared to $1.46 \%$ in 1986 due to the deposition of magma flow in to the Atlantic Ocean from the Mount Cameroon Volcanic eruption of the year 2000 causing a rise in the sea level.

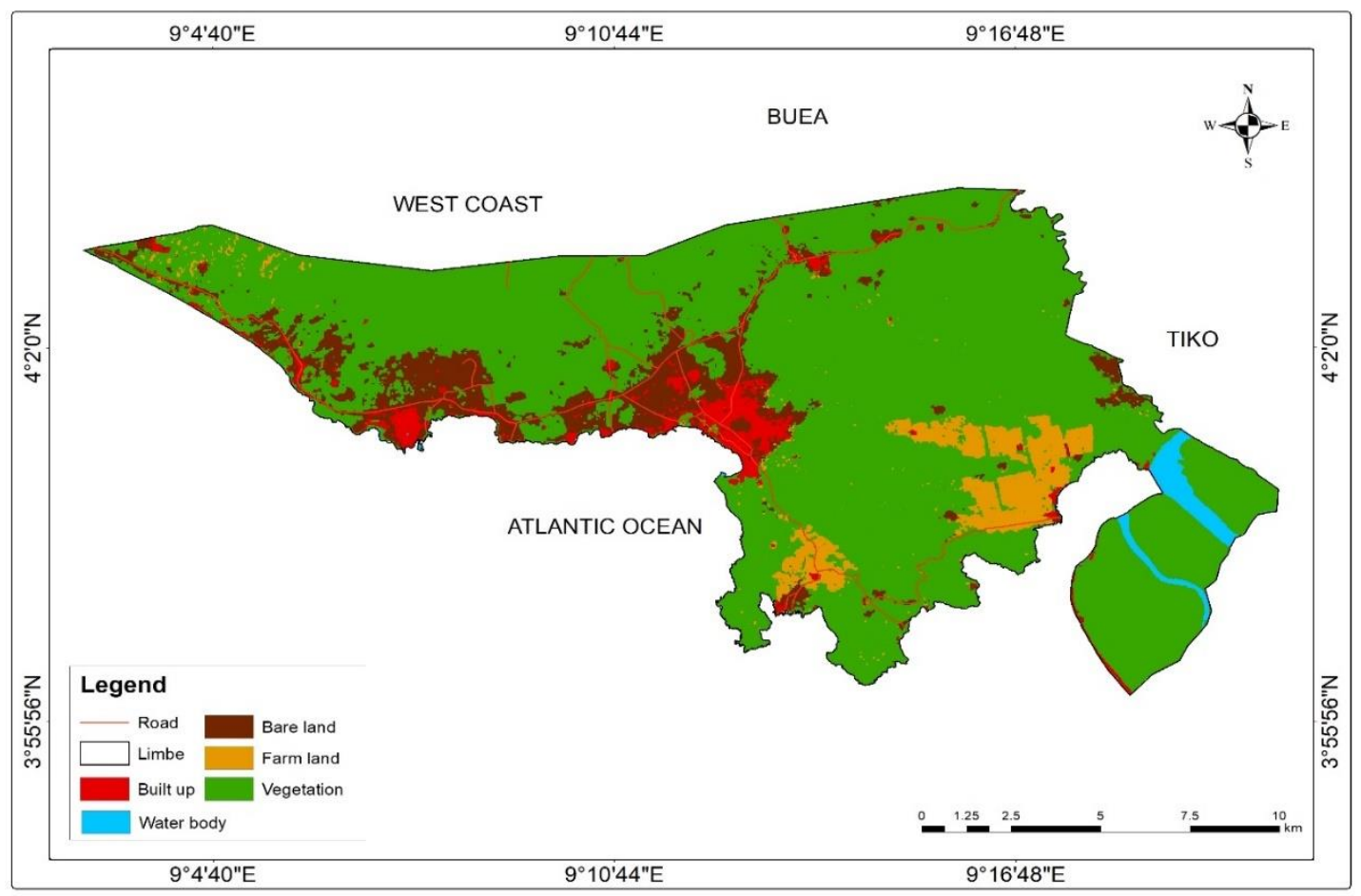

Figure 3: Land use/land cover map of 1986 


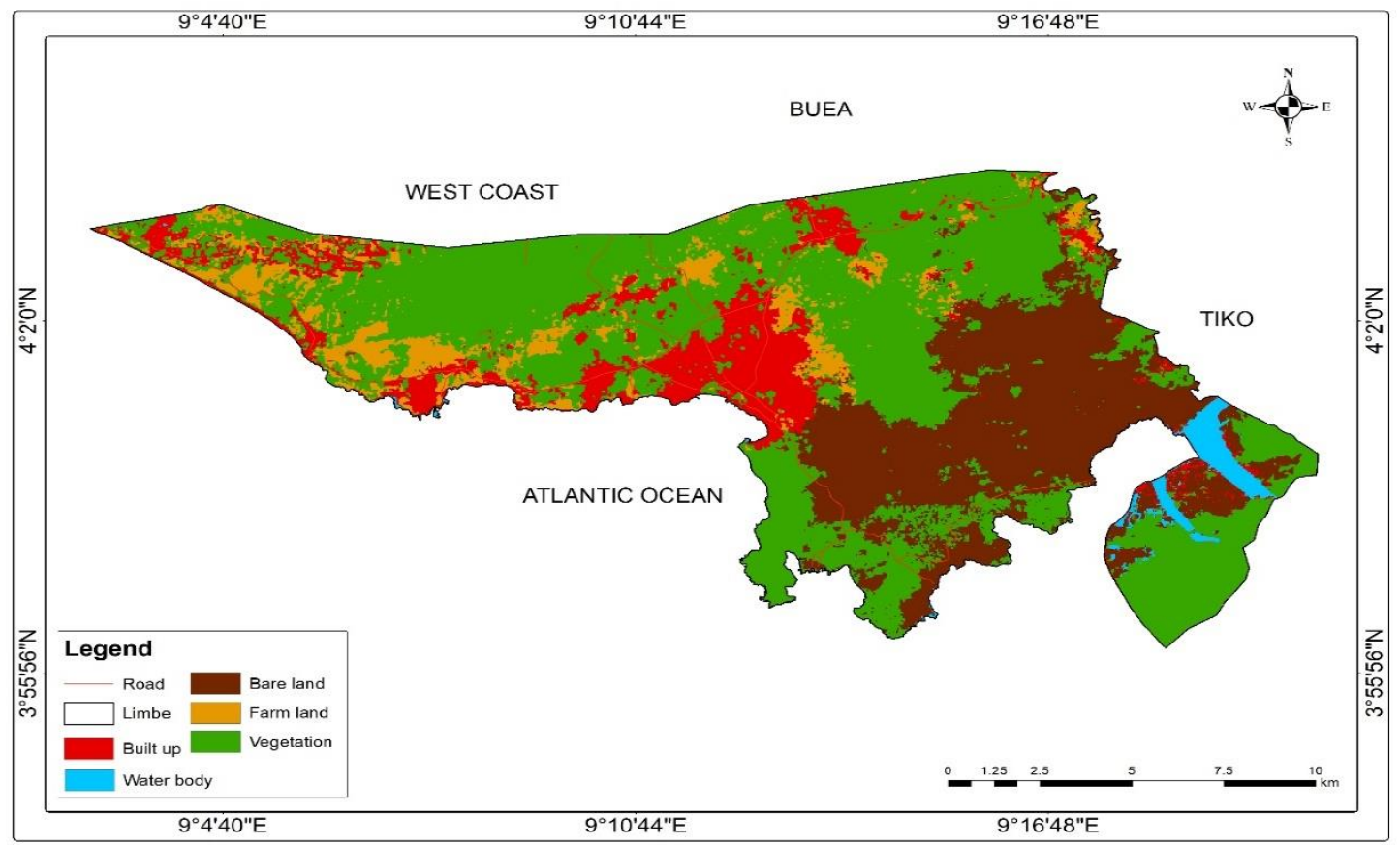

Figure 4: Land use/land cover map of 2002

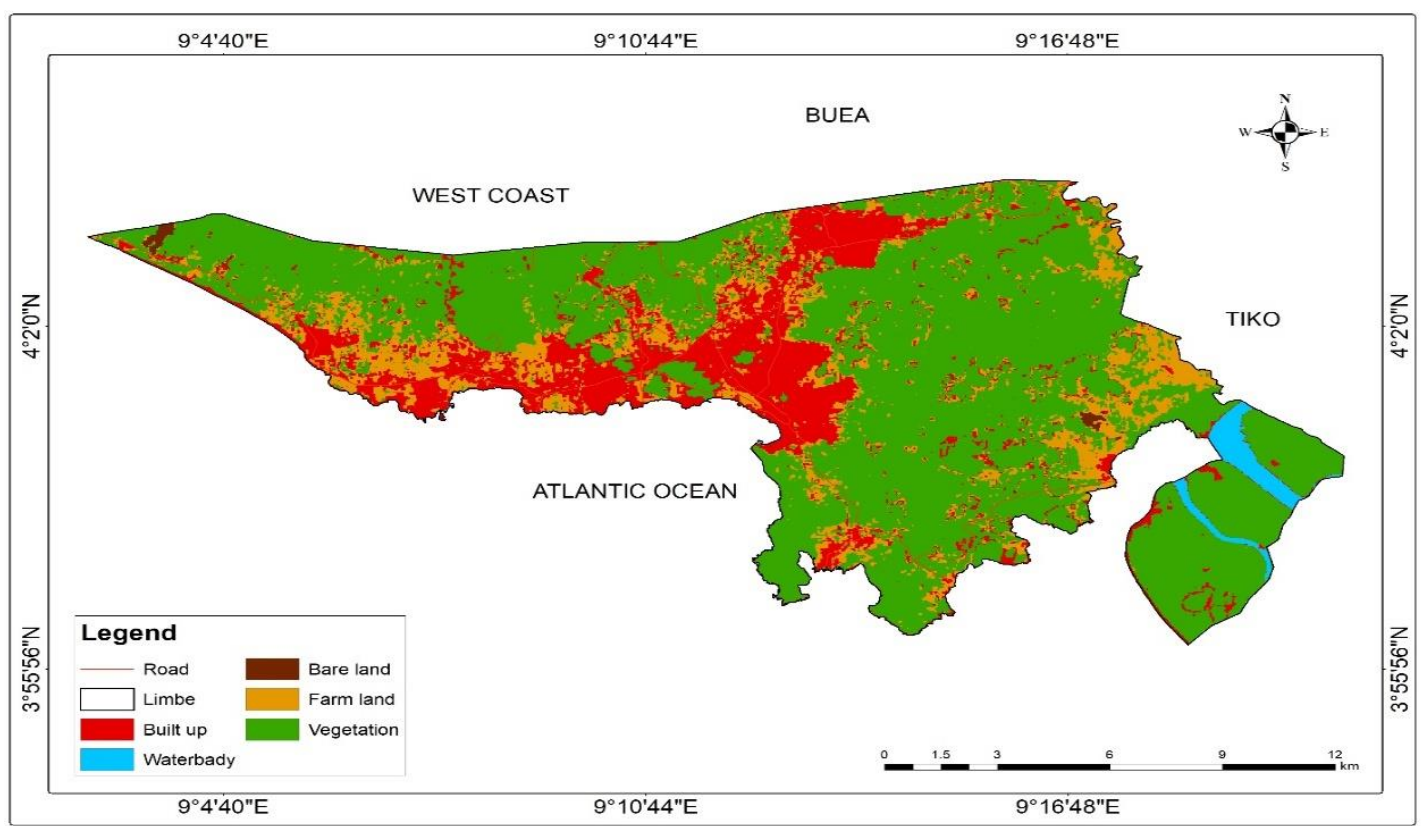

Figure 5: Land use/land cover map of 2019

By 2019, built up area has increased to $17.60 \%$ as the second highest. This is probably based on many factors such as establishment of schools, creation of social amenities, good security, construction of new roads, Stadia and creation of new layouts. Farmlands increase to $14.08 \%$ because of increase in population and also the fact that many indigenes of Limbe are farmers. Bare land reduced to $0.41 \%$ as to $24.48 \%$ in 2002 because of development associated with urbanization creation of layouts, construction of new Stadia as well as state low income houses and other social amenities not forgetting the sociopolitical crises that chased so many people away from the surrounding villages of Limbe. This also affected the vegetation positively as well. People fled from their homes as a result, vegetation covered the built up, bare land and farm lands. This can be observed in Table 3 .

\subsection{Land use/land cover change detection of Limbe city (1986-2019)}

Change in this study refers to the expansion and contraction of the various land use types between 1986 to 2002 and 2002 to 2019. The change detection analysis was done by subtracting the classification results of 1986 from 2002 and 2002 from 2019. Table 4 shows the matrix of transition from 1986-2019 and the changes are presented in area $\left(\mathrm{km}^{2}\right)$. 
Table 4: Matrix of transition for 1986-2019

\begin{tabular}{|c|c|c|c|c|c|c|}
\hline \multicolumn{7}{|l|}{ 1986-2002 } \\
\hline Classes & Built up $\left(\mathrm{km}^{2}\right)$ & Waterbody $\left(\mathrm{km}^{2}\right)$ & Bare land $\left(\mathrm{km}^{2}\right)$ & Farm land $\left(\mathrm{km}^{2}\right)$ & Vegetation $\left(\mathrm{km}^{2}\right)$ & Row total $\left(\mathrm{km}^{2}\right)$ \\
\hline Built up & 6.4323 & 0.072 & 8.0694 & 0.4104 & 11.9538 & 26.93 \\
\hline Waterbody & 0.0576 & 2.8053 & 0.0018 & 0 & 1.4427 & 4.30 \\
\hline Bare land & 0.4347 & 0 & 0.8145 & 9.0351 & 43.425 & 53.70 \\
\hline Farm land & 0.2043 & 0 & 2.9619 & 0.3501 & 14.6403 & 18.15 \\
\hline Vegetation & 0.8352 & 0.4104 & 10.4625 & 3.2166 & 102.4029 & 117.32 \\
\hline Class Total & 7.9641 & 3.2877 & 22.3101 & 13.0122 & 173.8647 & 220.22 \\
\hline \multicolumn{7}{|l|}{ 2002-2019 } \\
\hline Classes & Built up $\left(\mathrm{km}^{2}\right)$ & Waterbody $\left(\mathrm{km}^{2}\right)$ & Bare land $\left(\mathrm{km}^{2}\right)$ & Farm land $\left(\mathrm{km}^{2}\right)$ & Vegetation $\left(\mathrm{km}^{2}\right)$ & Row total $\left(\mathrm{km}^{2}\right)$ \\
\hline Built up & 13.3893 & 0.7839 & 1.4454 & 1.602 & 6.8454 & 24.06 \\
\hline Waterbody & 0.0495 & 2.7099 & 0 & 0 & 0.4005 & 3.15 \\
\hline Bare land & 0.3681 & 0.0135 & 0.2178 & 0.0126 & 0.0522 & 0.66 \\
\hline Farm land & 0.5958 & 0 & 2.2779 & 1.4373 & 3.6504 & 7.96 \\
\hline Vegetation & 12.5955 & 0.8136 & 49.7682 & 15.1047 & 106.3962 & 184.67 \\
\hline Class Total & 26.9982 & 4.3209 & 53.7093 & 18.1566 & 117.3447 & 220.22 \\
\hline
\end{tabular}

From 1986-2002, the change analysis result shows that a total of $6.4323 \mathrm{~km}^{2}$ out of $7.9641 \mathrm{~km}^{2}$ remain built up. Built up gained $0.072 \mathrm{~km}^{2}$ from waterbody, $8.0694 \mathrm{~km}^{2}$ from bare land, $0.4104 \mathrm{~km}^{2}$ from farm land and $11.9538 \mathrm{~km}^{2}$ from vegetation (as shown in Figure 6). This can be attributed to increasing level of urbanization within the study period.

From the year 2002-2019 built up maintain an area of $13.3893 \mathrm{~km}^{2}$ and loses up to $12.5955 \mathrm{~km}^{2}$ to vegetation. This situation is as a result of the socio-economic crises in the English-speaking part of Cameroon which started in 2016 and is ongoing which led to the burning of houses and abandonment of farm lands for safety. Built up gained $0.7839 \mathrm{~km}^{2}$ from waterbody, $1.4454 \mathrm{~km}^{2}$ from bare land, $1.602 \mathrm{~km}^{2}$ from farm land and $6.8454 \mathrm{~km}^{2}$ from vegetation, as shown in Table 4 and Figure 7.

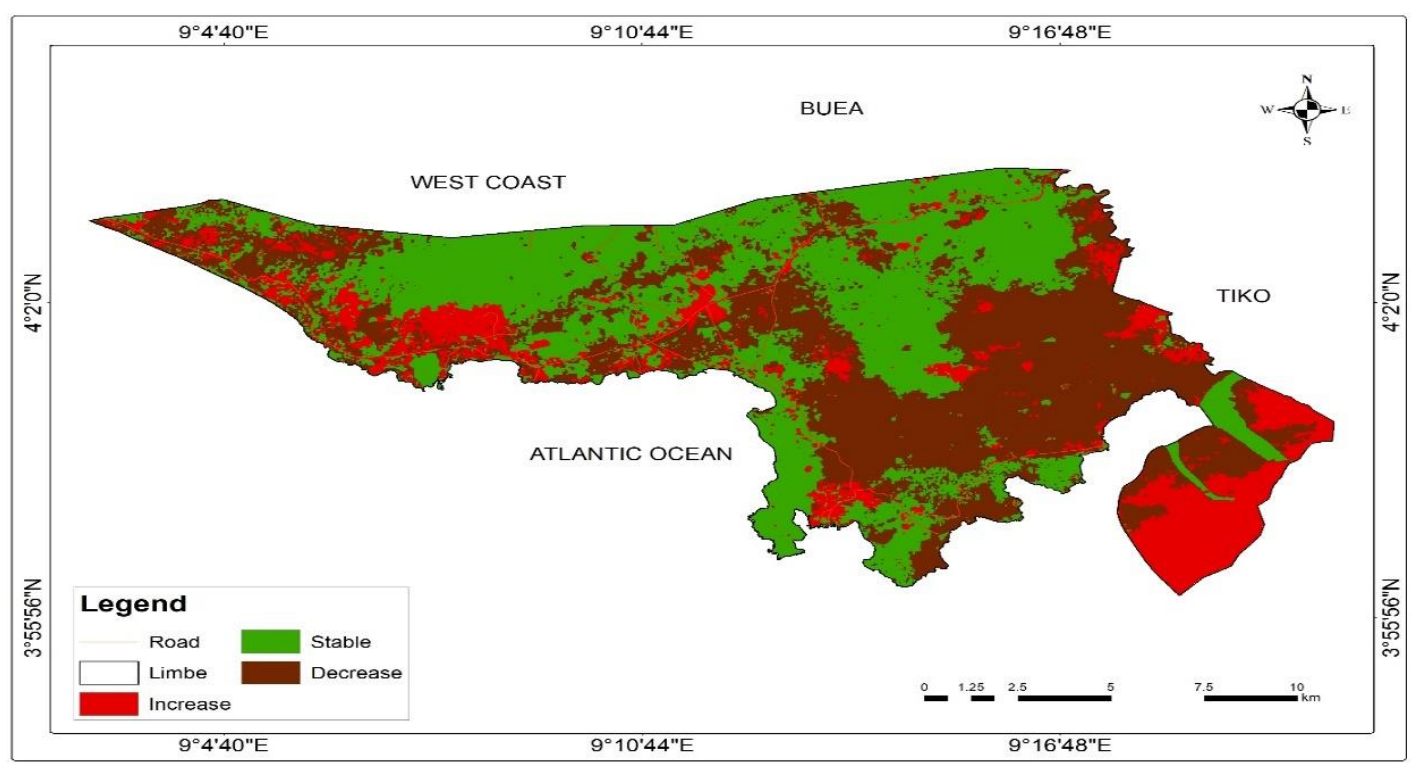

Figure 6: Change analysis for 1986-2002 


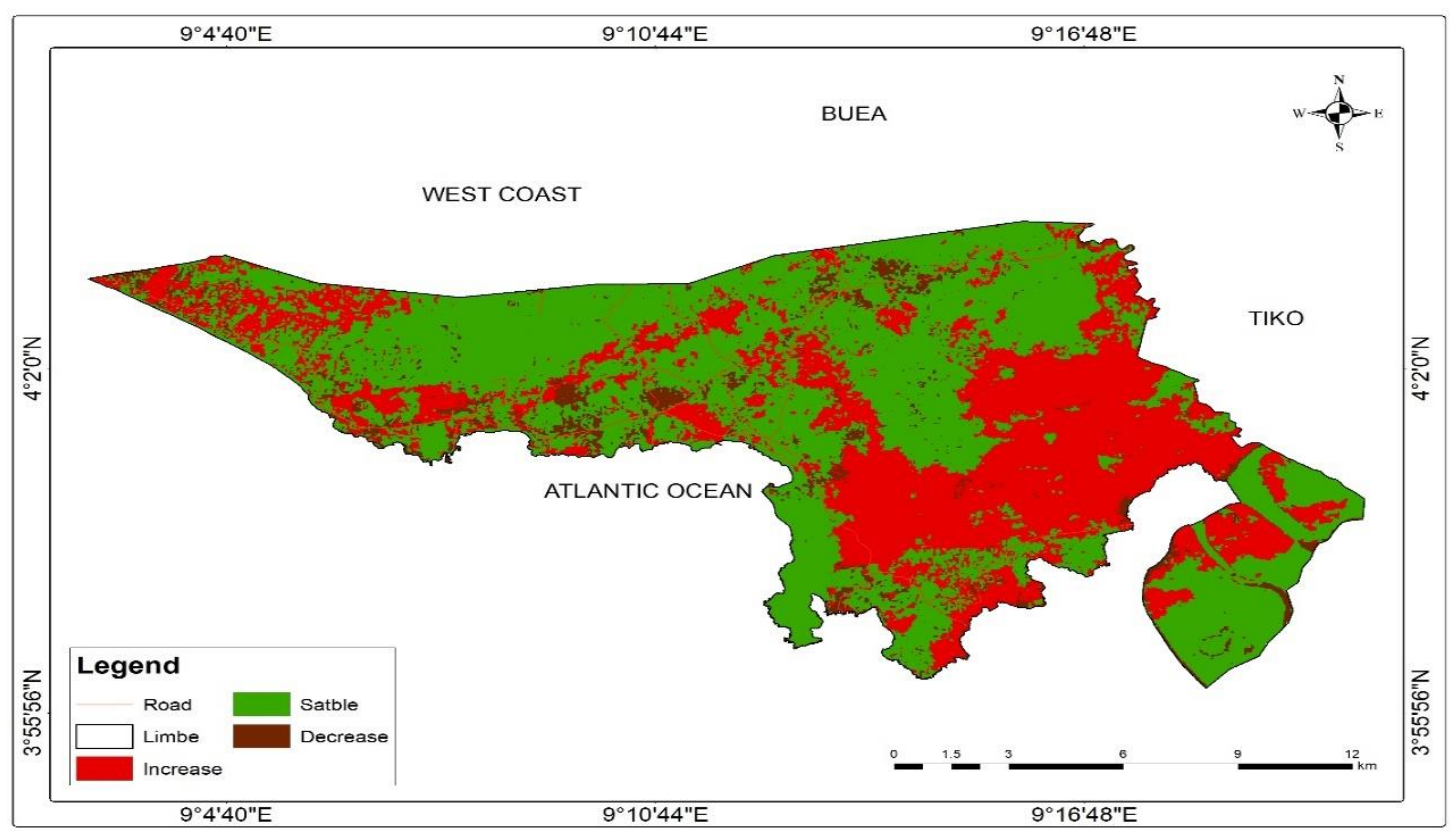

Figure 7: Change analysis for 2002-2019

\subsection{Urban growth modelling}

Urban growth analysis is conducted by developing comparison matrix of land cover for the year 1986 and 2002, 2002-2019. The matrix of land cover change shows that urban area gains about $10 \mathrm{~km}^{2}$ from other land covers such as vegetation, farm land, bare land and waterbody between1986-2002, waterbody and vegetation being the highest contributor to this gain. Waterbody within this same period gain the highest $110 \mathrm{~km}^{2}$ while farm land and bare land followed with $41 \mathrm{~km}^{2}$ and $30 \mathrm{~km}^{2}$ respectively. From 2002-2019, the built up step up to about $19.5 \mathrm{~km}^{2}$ gain, bare land being the highest contributor of $13 \mathrm{~km}^{2}$. Vegetation had $170 \mathrm{~km}^{2}$ gain, while farm land recorded $9 \mathrm{~km}^{2}$. Figure 8 shows the gains and losses between 1986 and 2019.
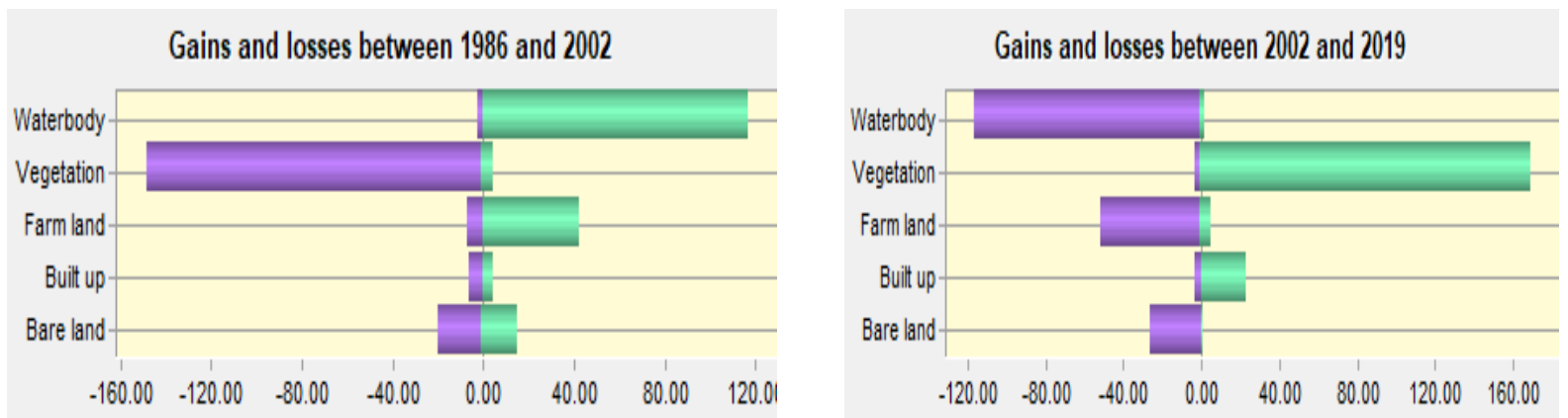

Figure 8: Change analysis of gain and loss bar graph between 1986-2002 and 2002-2019

\subsection{Logistic Regression Model}

Urban growth in this research is done using logistic regression model which calculates dependent and independent variables of urban growth. Urban growth data during 1986-2019 acts as dependent variable of logistic regression model, and suggested driving factors which drive urban growth as independent variables (Arsanjani et al., 2013). Table 5 and 6 indicate the individual regression coefficient and the logistic regression equation respectively.

Table 5: Individual regression coefficient

\begin{tabular}{lll}
\hline Factors & Variables & Coefficient \\
\hline Intercept & Intercept $(\beta 0)$ & -4.8112 \\
Distance from Urban area & $\operatorname{Urbandist}(\beta 1)$ & -1.4094 \\
Distance form Agriculture & Agricdist $(\beta 2)$ & 2.2039 \\
Distance from Road & Roaddist $(\beta 3)$ & 18.2941 \\
Distance from River & Riverdist $(\beta 4)$ & 2.2193 \\
\hline
\end{tabular}


Table 6: Logistic regression equation

\begin{tabular}{l} 
The Logistic function: $f(z)=\frac{1}{1+e^{-x}}$ \\
\hline$Z$ variable is defined as: \\
$Z=-4.8112-1.4094 *$ Urbandist $+2.2039 *$ Agricdist $+18.2941 *$ Roaddist $+2.2193^{*}$ \\
Waterdist
\end{tabular}

Source: Karsidi, 2011

The calculation of logistic regression model produces Pseudo $\mathrm{R}^{2}$ which indicates the fitness of relationship of the model. Thus, when pseudo $R^{2}=(0.2-0.4)$, indicates a perfect fit, whereas pseudo $\mathrm{R}^{2}=0$ indicates no relationship (Asep, 2011). The result shows that, Pseudo $\mathrm{R}^{2}=0.21$ while ROC was 0.8344 indicating the model was slightly a good fit; this is in line with (Karsidi, 2011). The results from Table 5 shows that the proximity variable, distance to roads $\left(\beta_{3}=18.2941\right)$ had the highest coefficients, distance to river variable $\left(\beta_{7}=2.2193\right)$ follow by distance to agriculture $\left(\beta_{4}=\right.$ 2.2039) showing the model had a best fit. The Relative Operation Characteristic (ROC) is an excellent method to compare a map of "reality" versus a suitability map according to (Hossein, 2019). ROC value ranges from 0 to 1 , where 1 indicates a perfect fit and 0.5 indicates a random fit. A ROC value between 0.5 and 1 indicates some association between the $\mathrm{X}$ variables and $\mathrm{Y}$. The larger the ROC the better the fit. Figures 9 to 14 shows the various independent variables used in building the Logistic Regression Model while Figure 15 shows the Logistic Regression Map.
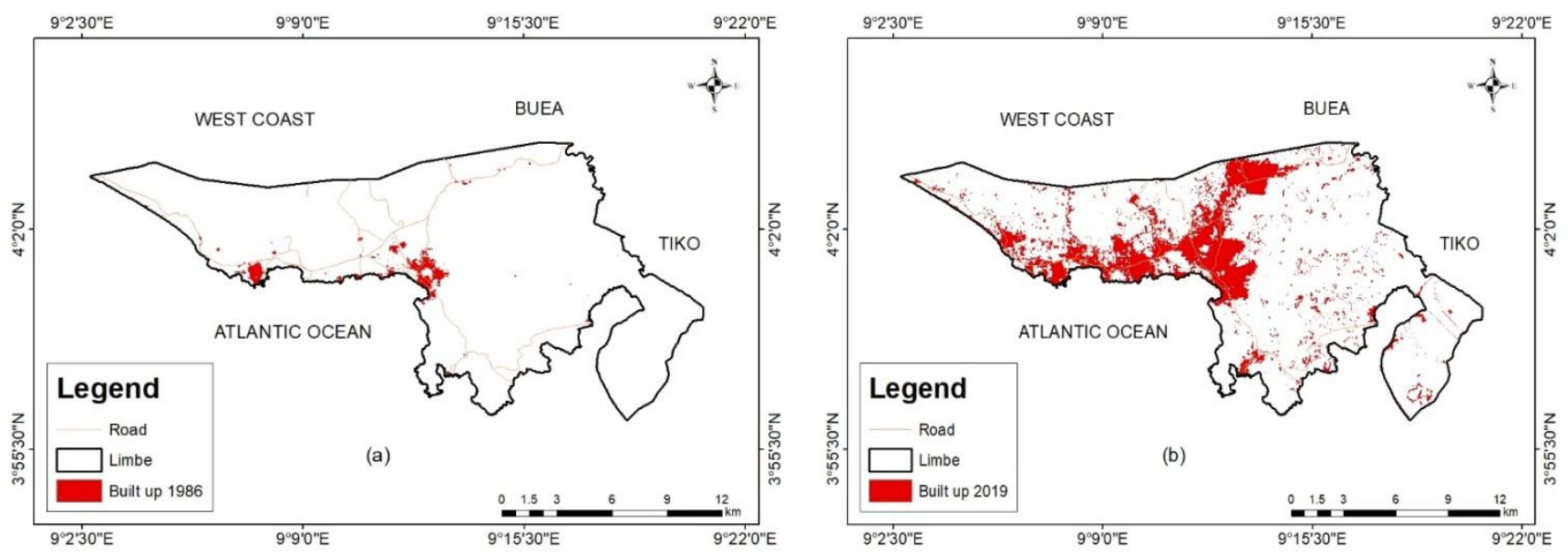

Figure 9: (a) Urban growth, 1986 and (b) Urban growth, 2019

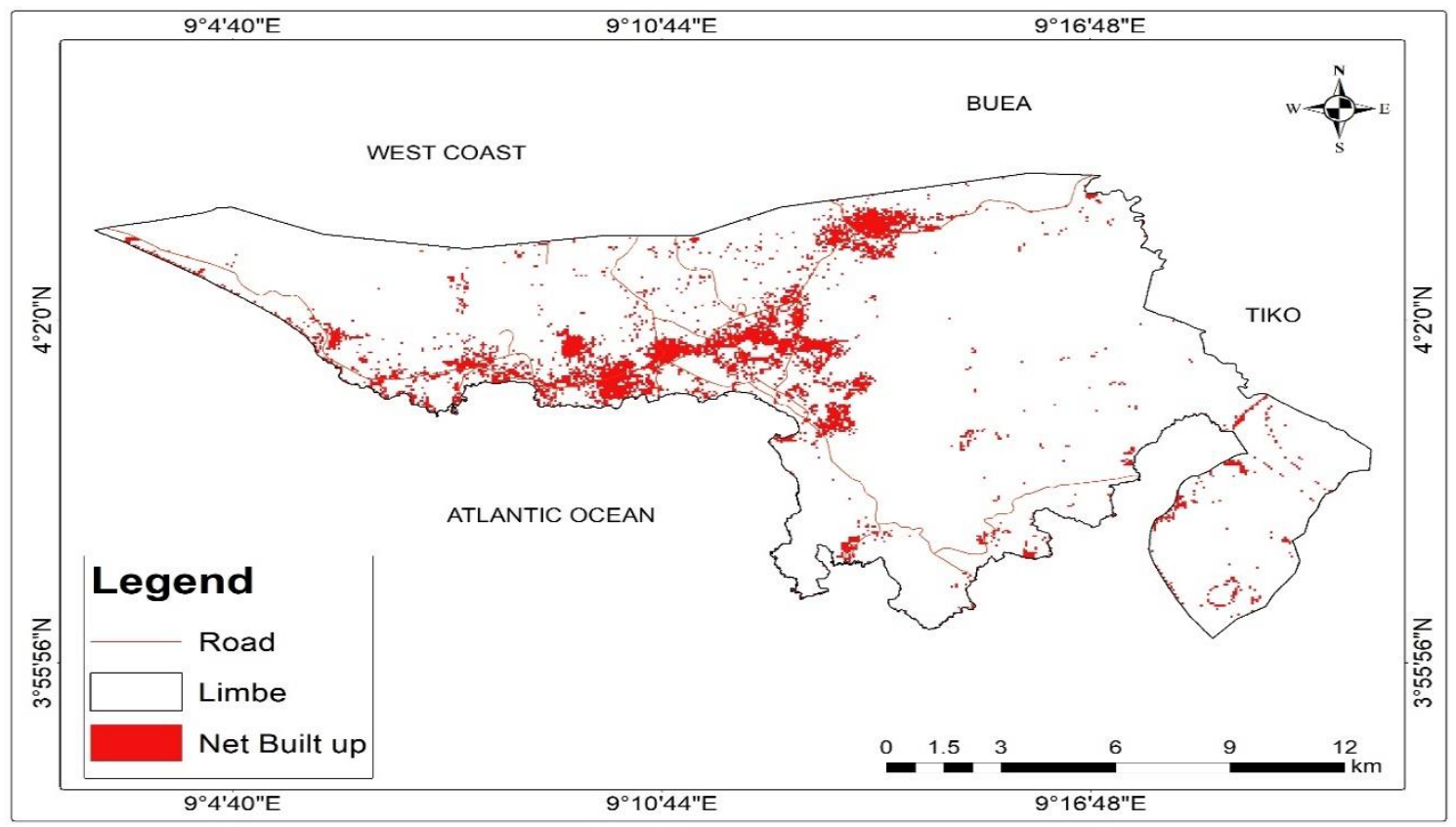

Figure 10: Net urban growth of Limbe during 1986-2019 

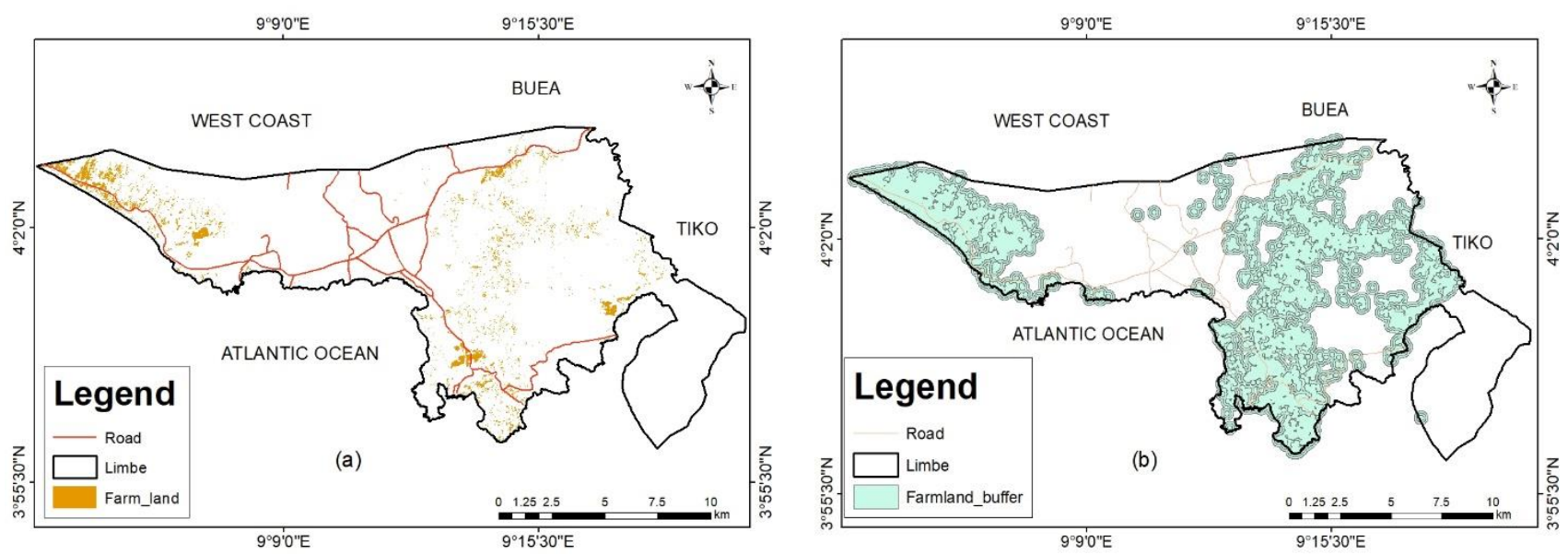

Figure 11: (a) Agriculture area map 2019 and (b) Agriculture area buffer
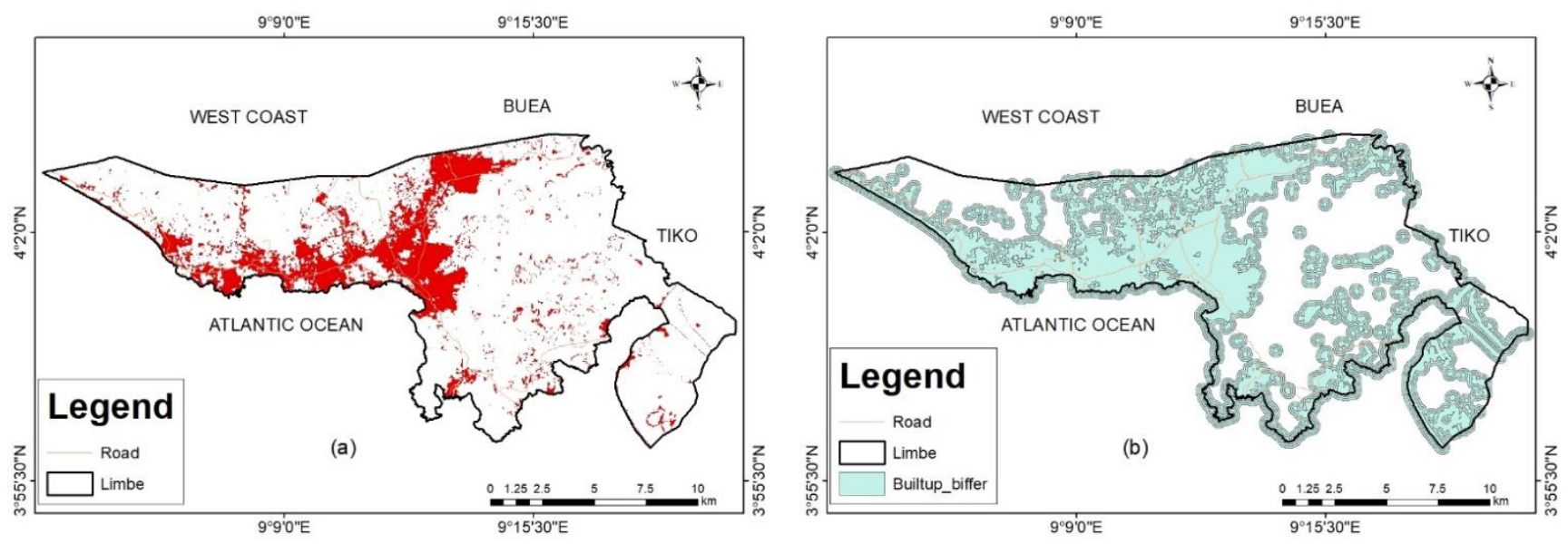

Figure 12: (a) Urban area map 2019 and (b) Urban area buffer
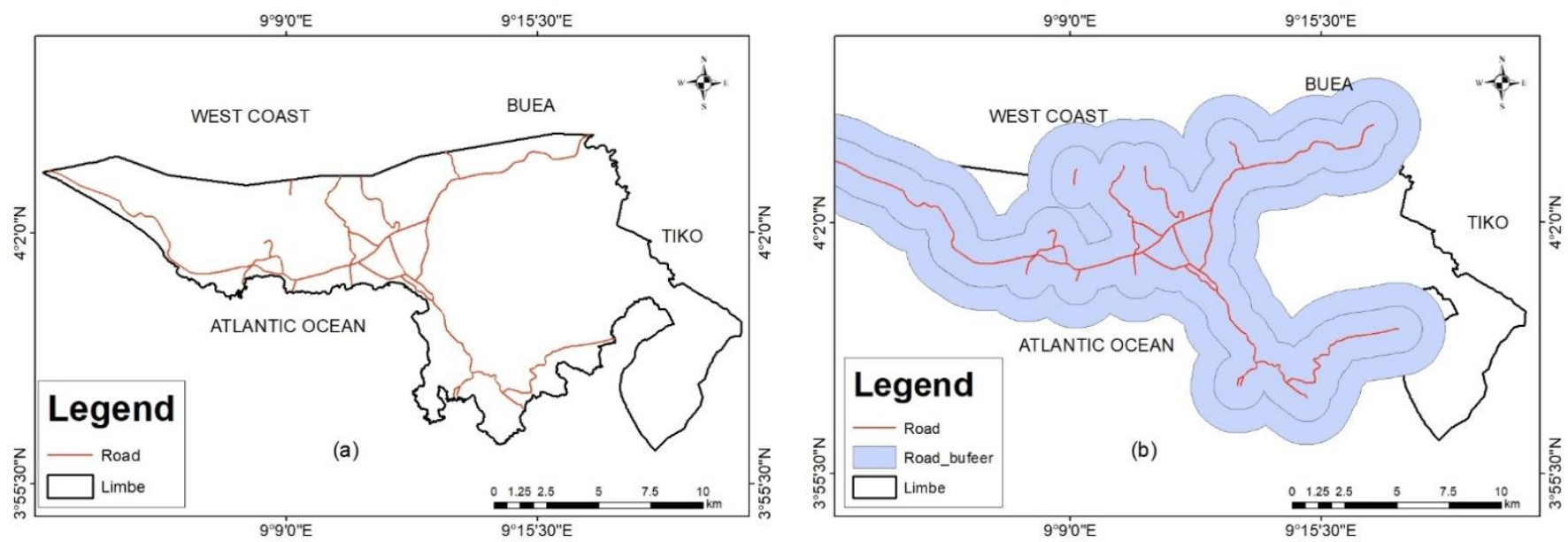

Figure 13: (a) Road map 2019 and (b) Road buffer 

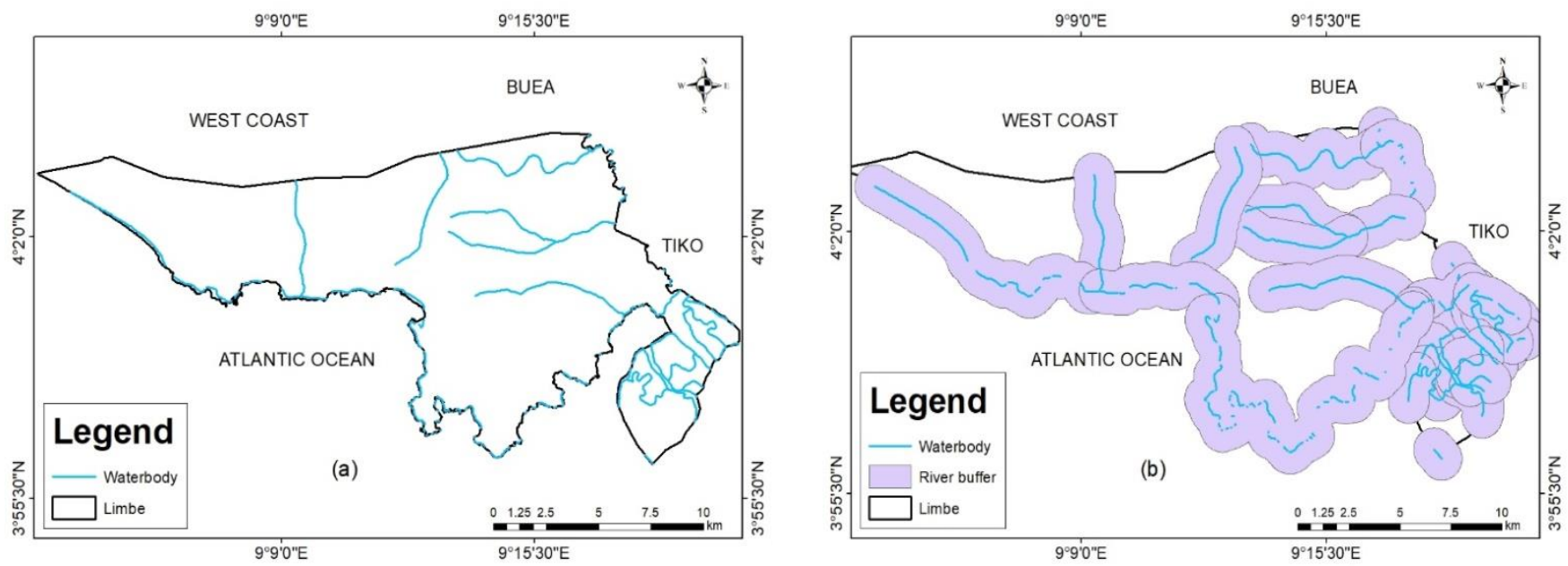

Figure 14: (a) River map 2019 and (b) River buffer

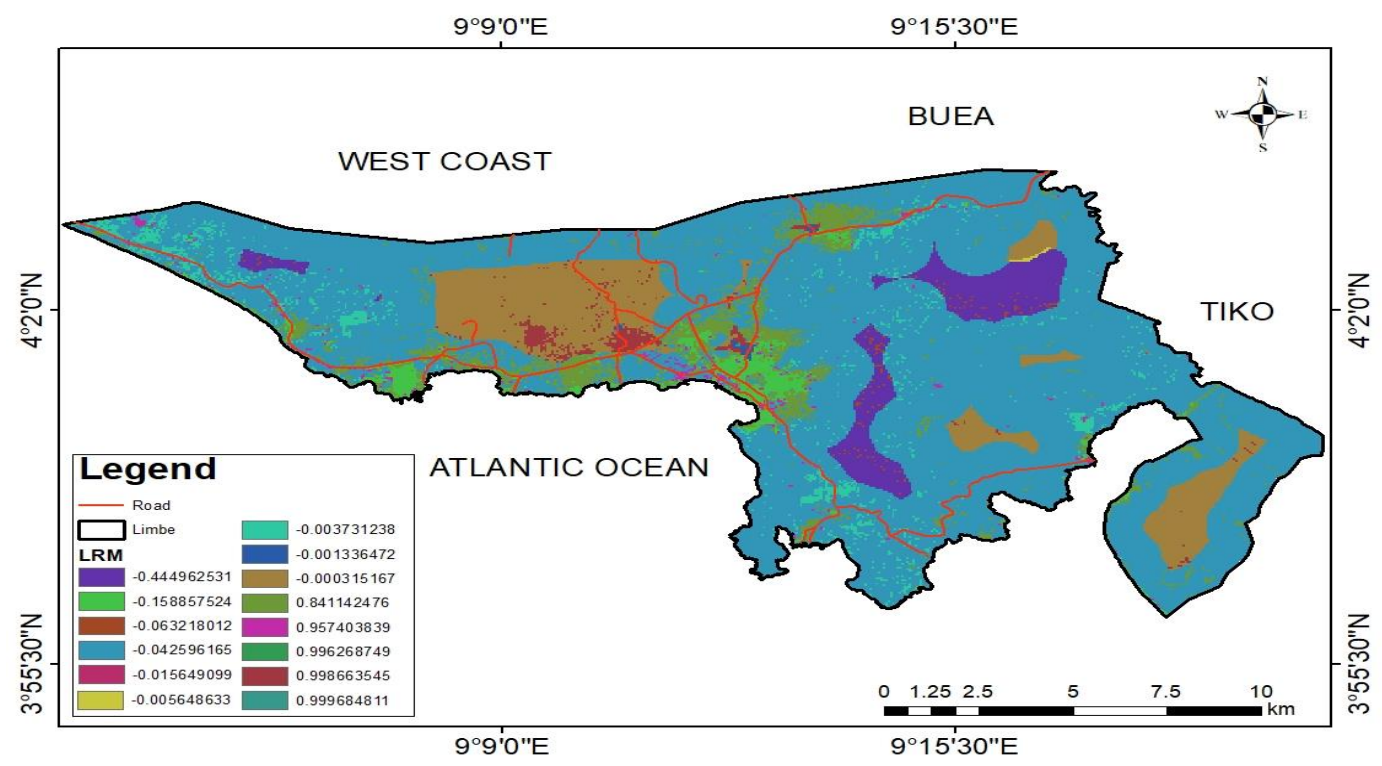

Figure 15: Logistic regression map for 1986-2019

Figure 9 and 10 shows the dependent variables which are maps of the urban growth area for 1986, 2019 as well as the net urban growth for the study period. Figure 11-14 are the maps showing the independent variables which include the agriculture area, river, road and urban maps and their buffers. Figure 15 indicates the LRM map for the study period.

\subsection{Land use/land cover prediction of Limbe for year 2035}

The prediction of land use for Limbe in 2035 is presented in transition probability matrix on table 7 . From the probability table, the probability for build up to remain build up by 2035 appears to be quite high at 0.6345 , while the probabilities for it changing to waterbody, bare land, farm land and vegetation are, $0.00,0.0174,0.0171$ and 0.9805 respectively. The probability of vegetation remaining vegetation is 0.9408 and the probability of it changing to build up, waterbody, farm land, bare land and vegetation stands at $0.1099,0.0459,0.1939$ and 0.1221 , respectively.

Also, the probability of farm land remaining farm land is below average 0.0056 . The probability for bare land to remain bare land is very slim, 0.3121 as indicated in Table 7 . This may be attributed to the fact that much of the bare lands will be converted to layouts for construction purpose. This is because the probability of bare land changing to build up is 0.3380 which is very high. Figure 16 shows the prediction expansion map of Limbe for the year 2035. 
Table 7: MARKOV transition probability matrix table

\begin{tabular}{llllll}
\hline Classes & Farm land & Built up & Bare land & Vegetation & Waterbody \\
\hline Farm land & 0.0056 & 0.0459 & 0.1421 & 0.8064 & 0.0000 \\
Built up & 0.0175 & 0.6345 & 0.0856 & 0.2601 & 0.0023 \\
Bare land & 0.0000 & 0.1939 & 0.3121 & 0.4941 & 0.0000 \\
Vegetation & 0.0009 & 0.1221 & 0.1305 & 0.7430 & 0.0035 \\
Waterbody & 0.0053 & 0.1099 & 0.0000 & 0.1672 & 0.7177 \\
\hline
\end{tabular}

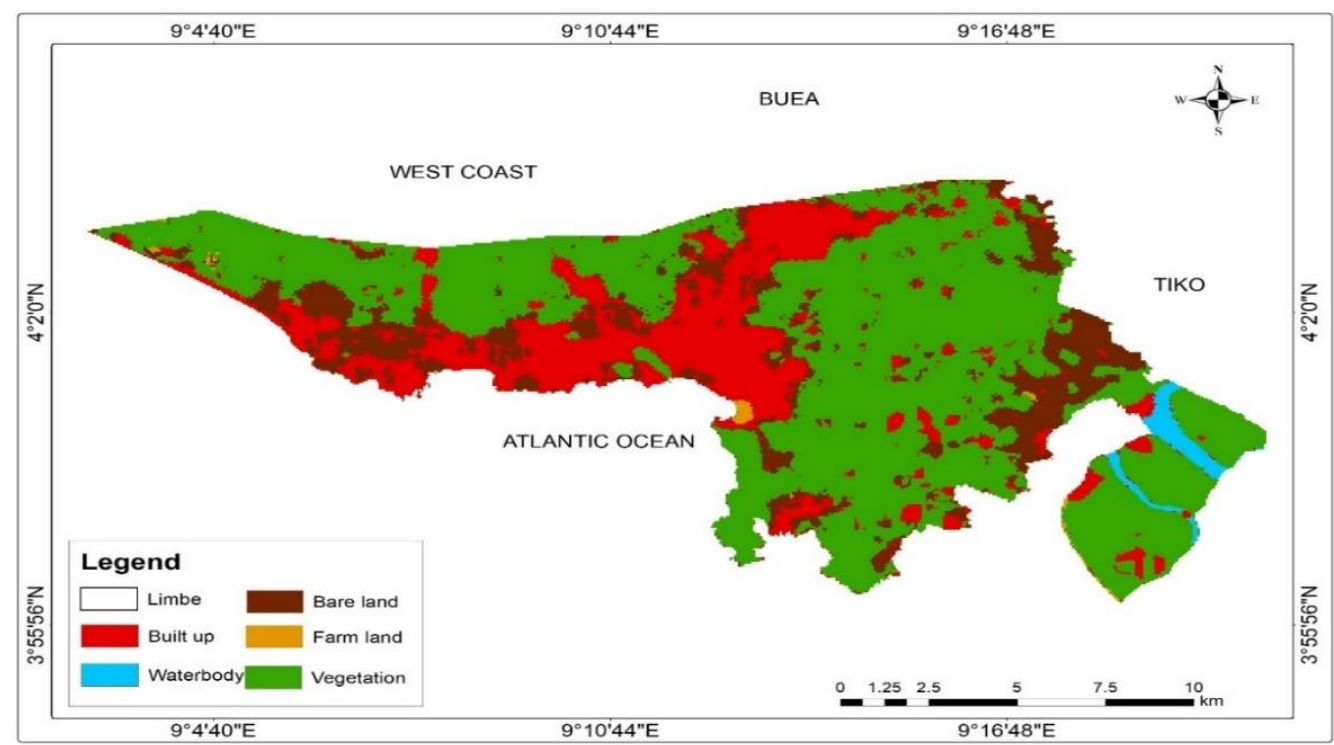

Figure 16: CA-MARKOV land use land cover for 2035

\subsection{Conclusions}

Urbanization is an inevitable process which increases with increase in population growth, industrialization and migration of people from rural areas in search of better living conditions. The aim of the present study is to form synergy with GIS and RS techniques and LRM to analyze and quantify urban growth patterns in Limbe city. This study specifically characterizes changes in LULC for the study period, model urban growth in the investigated area using LRM as well as project future growth rate for the year 2035. The projection date was chosen sequel to the Cameroon Vision 2035 that outlines the goals and priorities for the country in becoming an emerging economy by 2035 . The LULC change results indicated patterns of a degraded and disturbed LULC and a continuous increase in urban land area. LRM was used in modeling the urban growth process. This implies that, a high probability of urban growth areas is near major roads, rivers, and towards agriculture zone. The transition probability matrix projected for 2035 reveal high probability $(0.6345)$ for build up to remain build up by the year 2035. This study is successful in demonstrating the application of geo-spatial techniques and LRM for land use/land cover change detection and in understanding the urban growth dynamics. The study also helped in identifying the potential areas of future urban growth, which can help land use policy planners for making optimum decisions of land use planning and investment.

\section{References}

Addae, B. and Oppelt, N. (2019). Land-Use/Land-Cover Change Analysis and Urban Growth Modelling in the Greater Accra Metropolitan Area (GAMA), Ghana. Urban Science, 3, 26.

Anjolajesu, S. A. (2016). Examining the Lagos Green Initiative: A Case Study of Kosofe Local Government. International Journal of Sustainable Land use and Urban Planning, pp. 1-7.

Ankita, S. M. (2016). Analysis of Urban Growth using Geospatial Techniques. International Journal of Earth Sciences and Engineering, 9(6), pp. 2855-2861.

Arafan, T. T. (2017). Modeling Determinants of Urban Growth in Conakry, Guinea: A Spatial Logistic Approach. Graduate School of Environmental Science, Hokkaido University, Sapporo, Hokkaido, Urban Sci. 2017, 1, 12; doi:10.3390/urbansci1020012 www.mdpi.com/journal/urbansci. 
Asep, W. (2011). URBAN GROWTH PREDICTION USING LOGISTIC REGRESSION MODEL : Case Study in Bogor, West Java Province, Indonesia. National Coordinating Agency for Surveys and Mapping, 13(2), pp. 165 - 174.

Ashfa, A. S. (2015). Modelling of urban growth in tsunami-prone city using Logistic Regression. Applied Geography, 62, pp. 237-246.

Ayonghe, S. N., Ntasin, E. B., Samalang, P. and Suh, C. E. (2004). The June 27, 2001 landslide on volcanic cones in Limbe, Mount Cameroon, West Africa. Journal of African Earth Sciences, doi: 10.1016/j.jafrearsci.2004.07.022 .

Boakye, E. O. (2008). Landsat images for assessment of the impact of land use and land cover changes on the Barekese Catchment in Ghana. European Journal of Scientific Research, 22, pp. 269278.

Brueckner, J. K. (2011). Sprawl and blight. Journal of Urban Economics, 69(2), pp. 205-213.

Eastman, J. (2015). IDRISI TerrSet tutorial. Worcester, MA: Clark University, pp. 2-7.

Folack, J. A. (2003). Cameroon: Project brief on the integrated management of the Limbe-Kribi coastal area. 4th draft. Yaounde.

Grimm, N. G. (2000). Integrated Approaches to Long-Term Studies of Urban Ecological Systems. Bioscience, 50(7).

Hedblom, M. (2010). Long term monitoring of biodiversity and recreational values in Swedish urban green areas - methodology development. The Problems of Landscape Ecology, XXVIII, pp. 171-179.

Hossein, S.-M. (2019). Improving spatial accuracy of urban growth simulation models using ensemble forecasting approaches. Computers, Environment and Urban Systems, 76, pp. 91-100.

Karsidi, W. (2011). URBAN GROWTH PREDICTION USING LOGISTIC REGRESSION MODEL. National Coordinating Agency for Surveys and Mapping J1 Raya Jakarta Bogor KM 46 Cibinong, 13, pp. 156-174.

Ndille, R. B. (2014). Managing the Limbe Floods: Considerations for Disaster Risk Reduction in Cameroon. Int J Disaster Risk Sci, 5, pp. 147-156. doi: 10.1007/s13753-0140019-0.

Njabe, R. F. (2006). Illustrated physical geography and map reading for Cameroon. Limbe, Cameroon: Limbe: Sunway, pp. 12-35.

Nong, Y. Q. (2011). Urban growth pattern modeling using logistic regression. Geo-spatial Information Science, 14(1), pp. 62-67.

NRSC, L. U. (2014). Land Use / Land Cover database on 1:50,000 scale, Natural Resources Census Project, LUCMD, LRUMG, RSAA, National Remote Sensing Centre, ISRO, Hyderabad. Natural Resource Census- Land Use Land Cover, Ver 1, pp. 1-11.

Omar Hamdy, S. Z. (2017). Analyses the Driving Forces for Urban Growth by Using IDRISI®Selva Models Abouelreesh. International Journal of Engineering and Technology, 9(3).

Rawat, J. S. (2015). Monitoring Land use/cover change using Remote Sensing and GIS. The Egyptian Journal of Remote Sensing and Space Science, 18, pp. 77-84.

Roland, N. J. (2014). Managing the Limbe Floods: Considerations for Disaster Risk Reduction in Cameroon. International Journal of Disaster Risk Science, 5, pp. 147-156.

Steven J. and Burian, M. J. (2002). Evaluation of land use/land cover datasets for urban watershed modeling. Water Science and Technology, 45(9), pp. 269-276.

UN-Habitat. (2017). Dialogue on the Special Theme for the Twenty-Sixth Session of the Governing Council;. Nairobi, Kenya: Report of the Executive Director HSP/GC/26/5; UN-Habitat.

United Nations, D. P. (2016). sustainable urbanization strategy, UND P 's Support to Sustainable , inclussive and resilient cities in the developing world. Empowered lives.Resilient nations, pp. 10-20. 
UN-WCED, W. C. (1987). Our Common Future. Geneva, pp. 5-25: Gro Harlem Brundtland Oslo.

Yu Nong, Q. (2011). Urban growth pattern modeling using logistic regression. Geo-spatial Information Science, 14(1), pp. 62-67.

Zheng, H. W. (2015). Simulation Land use chnge in urban renewal areas: a case study in Hong Kong. Habitat International, 46, pp. 23-34. 